\title{
Total organic carbon and the humic fractions of the soil organic matter in silvopastoral system
}

\author{
Jefferson Rogério Marques da Silva ${ }^{1} \oplus$, Simone Cândido Ensinas ${ }^{2} \oplus$, Giselle Feliciani Barbosa ${ }^{1} \oplus$, \\ João Victor Oliveira Rezende ${ }^{1}\left[\right.$, Paulo Gabriel Vechetin Barreta ${ }^{1}{ }^{\oplus}$, Alan Mario Zuffo ${ }^{3} \odot$

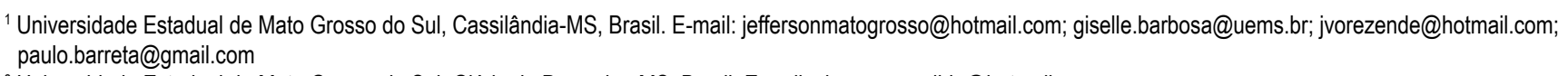

ABSTRACT: In agricultural production systems soil organic matter (SOM) is of paramount importance when assessing soil quality. Therefore, the objective of this study was to quantify the total organic carbon (TOC) and the humic fractions of the soil organic matter in silvopastoral system (SS) and to compare them with the conventional pasture system (CP) and a native vegetation area of Cerrado (NV). In the SS, soil samples were collected at distances 2.5, 5.0, 7.5 and $10 \mathrm{~m}$ from the eucalyptus row. Soil samples in each system were collected in the 0-10, 10-20 and 20-30 cm layers. The following parameters were determined: TOC, organic carbon associated with minerals (OCam), particulate organic carbon (OCp) and carbon of the humic soil substances. Carbon management index (CMI) and the sum of humic substances (SHs) were also calculated. SS was able to promote larger increases in the TOC, OCam and carbon stocks in the humic fractions when compared to CP and was also able to increase OCp and CMI values in depth. Soil sampling distances in the silvopastoral system had no significant influence on the changes in total carbon stocks and short-term SOM fractions. Furthermore, the land use with two years of SS implementation is not yet able to provide for most of the evaluated attributes with values equal to or higher than the soil with NV.

\section{Carbono orgânico total do solo e frações húmicas da matéria orgânica em sistema silvipastoril}

RESUMO: Em sistemas de produção agrícola a matéria orgânica do solo (MOS) é de suma importância na hora de avaliar a qualidade do solo. Diante disso, o trabalho teve como objetivos quantificar os estoques de carbono orgânico total (COT) e nas frações húmicas da matéria orgânica do solo em sistema silvipastoril (SS) e, compará-los com sistema de pastagem convencional (PC) e área de vegetação nativa de cerrado (VN). No SS foram coletadas amostras de solo nas distâncias 2,5, 5,0, 7,5 e $10 \mathrm{~m}$ da linha de plantio do eucalipto. As amostras de solo em cada sistema foram coletadas nas camadas de 0-10, 10-20 e 20-30 cm. Realizou-se a determinação do COT, carbono orgânico associado aos minerais (COam), carbono orgânico particulado (COp) e carbono das substâncias húmicas do solo. Foram calculados também o índice de manejo de carbono (IMC) e somatório das substâncias húmicas (SHs). O SS foi capaz de promover maiores incrementos nos estoques de COT, COam e carbono nas frações húmicas em comparação ao PC e, também foi capaz de aumentar os valores de COp e IMC em profundidade. As distâncias de coleta das amostras de solo no sistema silvipastoril não exerceram influências significativas nas alterações dos estoques de carbono total e nas frações da MOS em curto prazo. E o uso do solo com dois anos de implantação do SS ainda não é capaz de proporcionar para a maioria dos atributos avaliados valores iguais ou superiores ao solo com VN.

Palavras-chave: fracionamento; uso da terra; sistemas de manejo 


\section{Introduction}

Humanity has been facing increasing challenges in order to produce food, fibers, energy, timber and non-timber products in a compatible manner with the available natural resources (Cordeiro et al., 2015). Moreover, efforts are made aiming the reduction of greenhouse gas emissions from the agricultural activities.

Changes in the soil attributes occur with conversion of the native vegetation to cultivated systems, usually resulting in a decrease in the total organic carbon stocks and, consequently, a higher emission of greenhouse gases into the atmosphere (Resende et al., 2015; Freitas et al., 2018). However, using sustainable management practices can contribute to a new balanced state, also promoting beneficial effects for the soil.

Within this context, adopting sustainable agricultural practices is of great importance, such is the case of silvopastoral systems, which have significant potential in mitigating greenhouse gas emissions (Castro Neto et al., 2017; Schettini et al., 2017). They also contribute in increasing carbon storage potential in the soil by functioning as potential carbon sinks (Torres et al., 2014), providing an annual carbon increase of $3.124 \mathrm{tC}^{-1}$ (Castro Neto et al., 2017).

Studies have reported that conversion from native to cultivated areas, mainly with Eucalyptus plantations, can influence the dynamics of soil organic matter (Wink et al., 2015). This favors an increase in carbon stocks (Oliveira et al., 2016), even in subsurface layers of the soil (Lustosa Filho et al., 2017), also increasing carbon values in the humic fractions of organic matter in relation to areas that use only pasture (Loss et al., 2014).

Furthermore, by integrating tree, herbaceous and animal components, these systems bring about numerous benefits, such as the thermal comfort for animals, improvement in soil fertility, as well as improvements in erosion control, availability and quality of pasture, conservation of soil, water and biodiversity and diversification in the income of rural producers (Matoso \& Salman, 2016).

Assessing the benefits from good agricultural practices can be done by quantifying key indicators such as the soil carbon stocks (Oliveira et al., 2015; Kunde et al., 2018). However, there is often little change in the total organic carbon stocks in a short time span. Considering this, studies suggest using other SOM fractions for evaluating the effect of the land-use systems, emphasizing mainly the SOM granulometric fractions (particulate and associated with minerals organic carbons) and the humic fractions (fulvic acid, humic acid and humine) (Loss et al., 2014; Balin et al., 2017; Nanzer et al., 2019). In addition to these fractions, $\mathrm{CMI}$ can also be used as an alternative for assessing the soil quality, as values greater than 100 are an indicative that the agricultural production systems are being beneficial for the soil (Blair et al., 1995).

Despite the importance of quantifying the total organic carbon stocks and the SOM fractions when assessing the positive effects of agricultural production systems, there still is an information shortage in the literature quantifying and comparing silvopastoral systems with other systems of land use. Moreover, few studies take into account the effect of the distance gradient in the planting line on the organic matter stocks of the soil.

With this in mind, this study aimed to quantify the carbon stocks in the labile and recalcitrant fractions of the soil organic matter in a silvopastoral system with different sampling distances regarding the planting line, comparing them to the native vegetation area of Cerrado and the conventional pasture system.

\section{Materials and Methods}

A research was conducted in the municipality of Bandeirantes, located in Mato Grosso do Sul, at an average altitude of $630 \mathrm{~m}$ and a climate classified as rainy tropical (Aw) according to Köppen (1948), with an average precipitation of $1275 \mathrm{~mm}$ and an temperature of $23.1{ }^{\circ} \mathrm{C}$. The local soil was classified as (Neossolo Quartzarênico) (Santos et al., 2013) of a sandy texture (100 $\mathrm{g} \mathrm{kg}^{-1}$ of clay, $850 \mathrm{~g} \mathrm{~kg}^{-1}$ of sand and $50 \mathrm{~g}$ $\mathrm{kg}^{-1}$ of silt).

The treatments were represented by the silvopastoral system (SS), where samples collected at distances of: 2.5, 5.0, 7.5 and $10 \mathrm{~m}$ from the eucalyptus planting line; by the conventional pasture system (CP); and by the area of Cerrado native vegetation (NV).

The evaluated silvopastoral system had 120 hectares, implanted in the spring/summer of 2015/2016 with no soil correction, by using the $\mathrm{I}-144$ clone from Urograndis hybrid eucalyptus, homogeneously arranged in stands with three east/west rows, distanced $20 \mathrm{~m}$ apart, with $2.0 \mathrm{~m}$ between plants and $1.5 \mathrm{~m}$ between rows. The system was set up in an area of Urochloa brizantha, cv. BRS Marandu. 26-months-old Nelores heifers, with approximately $300 \mathrm{~kg}$ of live weight, were also put in the area in extensive grazing.

The conventional pasture also had 120 hectares, with no soil correction and the same pasture of Urochloa brizantha cv. BRS Marandu, formation time and stocking rate, but with no tree component. The native vegetation area had tree species from the Cerrado region and was characterized as a reserve area with no anthropic interference.

For collecting soil samples, the systems were subdivided into four sub-areas that corresponded to the replicates. In each one, soil collections were performed with a Dutch auger, in the layers of $0-10,10-20$ and $20-30 \mathrm{~cm}$, with four simple samples collected in order to compose one composite sample.

Evaluated attributes were the total organic carbon (TOC), organic carbon associated with minerals (OCam), particulate organic carbon (OCp) and the carbon in the fractions of the soil humic substances. The total organic carbon was obtained through the wet oxidation method with external heating, as described by Yeomans \& Bremner (1988). Alternatively, for obtaining OCp and OCam, the employed methodology was described by Cambardella \& Elliott (1992).

Humic substances (fulvic acid, humic acid and humine) were subjected to fractionation based on the differential 
solubility in acidic and alkaline solutions, according to the method of the international humic substances society (Swift, 1996). Lastly, the quantification of the total organic carbon levels in each humic fraction was performed according to Yeomans \& Bremner (1988).

The stocks of total organic carbon and carbon in the fractions of soil organic matter were all calculated by using the expression C Stock in $\mathrm{Mg} \mathrm{ha}{ }^{-1}=\left(\right.$ Carbon content in $\mathrm{g} \mathrm{kg}^{-1} \mathrm{X}$ soil density in $\mathrm{kg} \mathrm{dm}^{-3} \times$ soil layer thickness in $\mathrm{cm}$ )/10.

The Carbon Management Index (CMI) was obtained by the following expression: $\mathrm{CMI}=\mathrm{CCl} \times \mathrm{LI} \times 100$, where $\mathrm{CCl}$ is Carbon Compartment Index and LI is Lability Index (Blair et al., 1995).

The experiment was analyzed in a completely randomized design, with the data subjected to verification of normality of its distribution by the Lilliefors test, in order to verify the transformation need. Afterwards, the analysis of variance by the $F$ test was held and, when significant, the treatment means were grouped by the Scott-Knott test ( $p \leq 0.05)$. The used program for these procedures was the statistical software Assistat 7.7 (Silva \& Azevedo, 2016).

\section{Results and Discussion}

Regarding the stock of total organic carbon (TOC) and organic carbon associated with minerals (OCam) in all evaluated soil layers, the native vegetation of Cerrado (NV) was statistically superior in relation to other systems (Table 1). These results are related to the soil disturbance absence, presence of a large number of heterogeneous plant species with different root systems and due to the better physical conditions found in soils under native vegetation in function of the plant remains presence, which, when decomposed, increases the organic matter content of the soil (Nicodemo et al., 2018). Nanzer et al. (2019) also found higher stocks of TOC and OCam in areas of native vegetation and according to them this can be attributed to the anthropic action absence, which provides a favorable environment for maintaining soil organic matter related to the positive balance between entry and output of wastes.

The silvopastoral system, regardless of the collecting soil samples distance, showed statistical superiority when compared to the conventional pasture system, in the 10-20 cm layer, for the TOC and OCam stocks (Table 1). This demonstrates that even in the short-term adoption, silvopastoral systems can contribute in increasing the stocks of total organic carbon and carbon associated with minerals. The superiority of the silvopastoral system over using exclusive pasture for promoting a carbon stock increase in the system is related to the fact that this system is formed by different components (trees, grasses and animals) and benefits from their interaction (Bernardino \& Garcia, 2009).

In the silvopastoral system, tree species presence leads to reducing the incidence of solar radiation reaching the soil, thus decreasing the temperature and increasing soil moisture, which then favors the activity of microorganisms that act in the transformation process of organic waste. With this,
Table 1. Mean stocks from total organic carbon (TOC), organic carbon associated with minerals (OCam) and particulate organic carbon (OCp) in areas of native vegetation of Cerrado (NV), Urochloa brizantha cv. Marandu on conventional pasture (CP) and in silvopastoral system (SS) at different distances from the planting line.

\begin{tabular}{|c|c|c|c|c|}
\hline \multirow{2}{*}{ Treatments } & TOC & OCam & OCp & \multirow{2}{*}{ CMI } \\
\hline & \multicolumn{3}{|c|}{$\left(\mathrm{Mg} \mathrm{ha}^{-1}\right)$} & \\
\hline & \multicolumn{4}{|c|}{$0-10 \mathrm{~cm}$} \\
\hline NV & $21.79 a^{1}$ & $19.94 a^{1}$ & $1.85 \mathrm{a}$ & $100 a$ \\
\hline $\mathrm{CP}$ & $12.24 \mathrm{~b}$ & $11.37 \mathrm{~b}$ & $0.87 \mathrm{~b}$ & $44.91 b$ \\
\hline $\mathrm{SS}-2.5 \mathrm{~m}$ & $12.96 \mathrm{~b}$ & $11.56 \mathrm{~b}$ & $1.41 b$ & $74.33 b$ \\
\hline SS-5.0 m & $14.49 \mathrm{~b}$ & $13.34 \mathrm{~b}$ & $1.16 \mathrm{~b}$ & $55.14 b$ \\
\hline SS-7.5 m & $14.54 \mathrm{~b}$ & $13.31 \mathrm{~b}$ & $1.24 b$ & $64.68 \mathrm{~b}$ \\
\hline SS-10.0 m & $14.35 b$ & $13.08 \mathrm{~b}$ & $1.27 \mathrm{~b}$ & $62.74 \mathrm{~b}$ \\
\hline F Test & $7.5605^{* *}$ & $5.6788 * *$ & $4.798^{* *}$ & $5.9180 * *$ \\
\hline \multirow[t]{2}{*}{ CV (\%) } & 6.97 & 7.99 & 22.79 & 23.26 \\
\hline & \multicolumn{4}{|c|}{$10-20 \mathrm{~cm}$} \\
\hline NV & $19.54 \mathrm{a}$ & $18.73 \mathrm{a}$ & 0.81 & 100 \\
\hline $\mathrm{CP}$ & $10.00 \mathrm{c}$ & $8.69 \mathrm{c}$ & 1.31 & 98.05 \\
\hline SS-2.5 m & $15.23 b$ & $14.03 b$ & 1.25 & 137.71 \\
\hline SS-5.0 m & $14.77 \mathrm{~b}$ & $13.44 b$ & 1.32 & 142.23 \\
\hline SS-7.5 m & $13.94 \mathrm{~b}$ & $12.93 \mathrm{~b}$ & 1.01 & 120.05 \\
\hline SS-10.0 m & $12.64 \mathrm{~b}$ & $11.37 b$ & 1.27 & 143.67 \\
\hline F Test & $11.9158^{* *}$ & $16.3064^{* *}$ & $0.4342^{\text {ns }}$ & $0.5463^{\text {ns }}$ \\
\hline \multirow[t]{2}{*}{ CV (\%) } & 12.76 & 12.46 & 53.83 & 45.62 \\
\hline & \multicolumn{4}{|c|}{$20-30 \mathrm{~cm}$} \\
\hline NV & $17.52 \mathrm{a}$ & $16.85 \mathrm{a}$ & $0.67 b$ & $100 \mathrm{~b}$ \\
\hline $\mathrm{CP}$ & $10.59 \mathrm{~b}$ & $10.00 \mathrm{~b}$ & $0.59 \mathrm{~b}$ & $78.15 b$ \\
\hline SS-2.5 m & $12.48 b$ & $10.70 \mathrm{~b}$ & $1.78 \mathrm{a}$ & $249.69 a$ \\
\hline $\mathrm{SS}-5.0 \mathrm{~m}$ & $13.64 \mathrm{~b}$ & $12.06 \mathrm{~b}$ & $1.58 \mathrm{a}$ & $216.79 a$ \\
\hline SS-7.5 m & $11.94 \mathrm{~b}$ & $10.46 b$ & $1.53 \mathrm{a}$ & $220.93 a$ \\
\hline SS-10.0 m & $12.97 \mathrm{~b}$ & $10.07 b$ & $1.90 \mathrm{a}$ & $174.41 \mathrm{a}$ \\
\hline F Test & $10.6914^{* *}$ & $11.5847^{* *}$ & $3.1418^{*}$ & $7.2706^{* *}$ \\
\hline CV (\%) & 10.91 & 12.60 & 47.82 & 29.76 \\
\hline
\end{tabular}

Means followed by the same letter, in the columns, belong to the same group by the Scott-Knott clustering test. By $\mathrm{F}$ Test $* *$ significant at $1 \%$ of probability, ${ }^{*}$ significant at $5 \%$ of probability, ${ }^{\text {ns }}$ not significant. ${ }^{1}$ Data transformed in $1 / V x$, but with original means displayed in Table 1.

an increase in the rate of cycling of nutrients occurs, which will favor the development of trees and pasture alike, thus promoting a greater plant growth and, consequently, a greater addition of waste to the soil (Bernardino \& Garcia, 2009).

In addition to the benefits of the organic waste from animals in the area that also contribute to higher amounts of carbon in the soil (Ferreira et al., 2019), the action of this process over time tends to stabilize the organic matter contents in a new balance (Campanha et al., 2009). This promotes a greater input of organic carbon to the soil and the formation of more stable fractions of organic matter.

$\mathrm{NV}$ in the $0-10 \mathrm{~cm}$ layer had the largest stocks of particulate organic carbon (OCp) (Table 1), which is the result of the large deposition of plant residues on the soil surface. Moreover, the studied native vegetation area had a wide variety of plant species and dense vegetation, with decomposition of plant remains at different velocities, which contributes in maintaining the carbon content in the labile fractions of the soil organic matter. In a study by Balin et al. (2017), the OCp fraction of native vegetation represented $73 \%$ from the 
TOC content in the superficial layer $(0-5 \mathrm{~cm})$. According to these authors, in a native vegetation area, the presence of more aliphatic compounds in the residues deposited in the superficial layer of the soil takes place.

For OCp in the $20-30 \mathrm{~cm}$ layer, the silvopastoral system, regardless the distance of the soil samples collection, had the largest stocks, statistically differing from the NV and from the conventional pasture system. In the silvopastoral system, there is a large amount of waste input from both grasses and tree species; moreover, the root system of these plant species allows carbon in the soil at greater depths. The OCp increase in the silvopastoral system was reported by Loss et al. (2014), and according to these authors, this can be attributed to the diversification of plants providing a greater input of plant residues and their positive effect on soil aggregation. The grasses also have an abundant and bulky root system, frequently renewed, providing a large amount of organic matter to the subsurface soil (Mascarenhas et al., 2017).

For the carbon management index (CMI) in the 0-10 $\mathrm{cm}$ layer, the highest value was found in the area of native vegetation of Cerrado, statistically differing from the other evaluated systems. For the $20-30 \mathrm{~cm}$ layer, a statistical superiority of the silvopastoral system was found in all collection distances of soil samples (Table 1 ).

The CMI superiority of the silvopastoral system is possibly due to the preservation of organic compounds, since the consortium of eucalyptus and grasses provides the addition of organic residues high in lignin content, which in turn hinders the microbial attack. Allied to the constant deposition of plant residues by tree species are the non-disturbance of the soil and the manure input by animals, which contributes to higher $\mathrm{CMI}$ values.

Regarding the sum of humic substances (SHs), the silvopastoral system showed statistical superiority in all sampled distances in relation to the conventional pasture system, for the 0-10 and 10-20 cm layers; however, it did not present statistical differences in relation to the NV. In the 20$30 \mathrm{~cm}$ layer, NV had the largest SHs stocks (Table 2).

In the conventional system, the pasture is degraded proportionally to the organic matter due to the dry season and the animals constantly feeding (Muller et al., 2002), which contribute to the decrease of SHs stocks in this landuse system. This is mainly because the greater oxidation of organic matter in pastures that are degraded or in the process of degradation, making the production of forage biomass insufficient in maintaining carbon stocks in the soil (Braz et al., 2013). On the other hand, in native vegetation areas, the higher values for $\mathrm{SH}$ s can be attributed to the natural dynamics of the system that favor the maintenance and incorporation of soil organic matter (Brasil Neto et al., 2018).

Regarding the C-FA stock, the silvopastoral system in the 10-20 cm layer was superior to the conventional system. Moreover, for the $20-30 \mathrm{~cm}$ layer, the NV and the silvopastoral system at a distance of $2.5 \mathrm{~m}$ had the highest C-FA stocks, differing statistically from other treatments. The conventional system had the lowest values for C-HA stock in all evaluated layers.
Table 2. Means from the sum of the carbon stocks of humic substances (SHs), carbon in the fraction of fulvic acid (C-FA), carbon in the fraction of humic acid (C-HA), carbon in the humine fraction (C-Hum) and the C-HA/C-FA ratio in areas of native vegetation of Cerrado (NV), pasture of Urochloa brizantha cv. Marandu on conventional pasture (CP) and silvopastoral (SS) systems at different distances from the planting line.

\begin{tabular}{|c|c|c|c|c|}
\hline \multirow{2}{*}{ Treatments } & SHs & C-FA & C-HA & C-Hum \\
\hline & \multicolumn{4}{|c|}{$\left(\mathrm{Mg} \mathrm{ha}^{-1}\right)$} \\
\hline & \multicolumn{4}{|c|}{$0-10 \mathrm{~cm}$} \\
\hline NV & $17.50 \mathrm{a}$ & 2.85 & $5.68 \mathrm{a}$ & $8.97 \mathrm{a}$ \\
\hline $\mathrm{CP}$ & $9.34 \mathrm{c}$ & 1.53 & $1.49 \mathrm{c}$ & $6.70 \mathrm{~b}$ \\
\hline SS-2.5 m & $12.95 b$ & 1.77 & $3.20 \mathrm{~b}$ & $7.97 \mathrm{~b}$ \\
\hline SS-5.0 m & $13.96 \mathrm{~b}$ & 1.87 & $3.09 \mathrm{~b}$ & $8.99 a$ \\
\hline SS-7.5 m & $14.41 \mathrm{~b}$ & 1.76 & $2.75 \mathrm{~b}$ & $9.91 \mathrm{a}$ \\
\hline SS-10.0 m & $14.20 \mathrm{~b}$ & 1.83 & $3.07 \mathrm{~b}$ & $9.30 \mathrm{a}$ \\
\hline F Test & $5.9101^{* *}$ & $2.2567^{\mathrm{ns}}$ & $22.0471^{* *}$ & $3.0657^{*}$ \\
\hline \multirow[t]{2}{*}{ CV (\%) } & 14.98 & 14.86 & 18.09 & 15.02 \\
\hline & \multicolumn{4}{|c|}{$10-20 \mathrm{~cm}$} \\
\hline NV & $18.45 a$ & $2.65 a^{1}$ & $5.83 a^{1}$ & $9.97 \mathrm{a}$ \\
\hline $\mathrm{CP}$ & $9.44 \mathrm{c}$ & $1.01 \mathrm{c}$ & $1.35 \mathrm{c}$ & $7.07 \mathrm{~b}$ \\
\hline SS-2.5 m & $14.14 b$ & $1.59 \mathrm{~b}$ & $2.49 \mathrm{~b}$ & $10.05 a$ \\
\hline SS-5.0 m & $14.33 b$ & $1.52 \mathrm{~b}$ & $2.66 \mathrm{~b}$ & $10.13 \mathrm{a}$ \\
\hline SS-7.5 m & $13.94 \mathrm{~b}$ & $1.67 \mathrm{~b}$ & $2.55 \mathrm{~b}$ & $9.71 \mathrm{a}$ \\
\hline SS-10.0 m & $12.60 \mathrm{~b}$ & $1.66 \mathrm{~b}$ & $2.44 \mathrm{~b}$ & $8.50 \mathrm{~b}$ \\
\hline F Test & $11.5477^{* *}$ & $22.1102 * *$ & $31.8694 * *$ & $3.0123 *$ \\
\hline \multirow[t]{2}{*}{ CV (\%) } & 12.41 & 13.43 & 8.05 & 15.21 \\
\hline & \multicolumn{4}{|c|}{$20-30 \mathrm{~cm}$} \\
\hline NV & $16.75 \mathrm{a}$ & $2.22 \mathrm{a}$ & $5.94 \mathrm{a}$ & 8.58 \\
\hline $\mathrm{CP}$ & $10.35 b$ & $1.18 \mathrm{~b}$ & $1.37 \mathrm{c}$ & 7.79 \\
\hline SS- $2.5 \mathrm{~m}$ & $12.28 b$ & $1.89 a$ & $2.08 \mathrm{~b}$ & 8.30 \\
\hline SS-5.0 m & $9.75 b$ & $1.46 \mathrm{~b}$ & $1.85 \mathrm{~b}$ & 6.44 \\
\hline SS-7.5 m & $8.62 b$ & $1.49 \mathrm{~b}$ & $2.06 \mathrm{~b}$ & 5.06 \\
\hline SS-10.0 m & $9.67 b$ & $1.48 \mathrm{~b}$ & $1.63 \mathrm{c}$ & 6.56 \\
\hline F Test & $8.9540^{* *}$ & $4.2442^{*}$ & $135.829 * *$ & $2.5178^{\text {ns }}$ \\
\hline CV (\%) & 17.61 & 22.29 & 11.82 & 23.76 \\
\hline
\end{tabular}

Means followed by the same letter, in the columns, belong to the same group by the Scott/-Knott clustering test. By F Test ** significant at $1 \%$ of probability, * significant at $5 \%$ of probability, ${ }^{\text {ns }}$ not significant. ${ }^{1}$ Data transformed in $1 / \mathrm{Vx}$, but with original means displayed in Table 2.

Loss et al. (2014) found similar results, reporting that in silvopastoral systems there are increases in the values of C-FA and C-HA. According to these authors, this result is attributed to the litter from the trees and the rhizodeposition of the pastures. Increasing deposition of organic waste with a high $\mathrm{C} / \mathrm{N}$ ratio favors the SOM humidification process and, consequently, the organic matter accumulation in protected compartments (Lima et al., 2008).

Regarding C-Hum stocks, the lowest values were found in the $0-10 \mathrm{~cm}$ layer for the conventional system and silvopastoral system at a distance of $2.5 \mathrm{~m}$, and in the 10-20 layer both in the conventional system and silvopastoral system at a distance of $10.0 \mathrm{~m}$ (Table 2). The lower C-Hum values in the conventional grazing system may be associated with less addition of plant residues and greater degradation of the soil organic matter. Usually in the conventional system, extensive grazing is not planned to adapt itself to the regeneration time of forages, and thus forage plants lose their production capacity over 
time, compromising the cycling of nutrients and the addition of organic matter to the soil (Ferreira et al., 2010), mainly reducing the carbon stocks in its most stable fractions. Similar results were found by Baldotto et al. (2015), who reported that systems with exclusive use of grasses have lower carbon values in the humine fraction when compared to systems with the presence of tree species.

Accumulation of carbon in the humic fractions of organic matter followed the order: C-Hum, C-HA and C-FA in all landuse systems. Baldotto et al. (2015) also observed this trend, so that the more stable the land-use system is, the higher the values observed in C-Hum will be. According to Loss et al. (2014), in most soils, the most recalcitrant forms of SOM (humid fraction and humic acid fraction) are dominant in quantitative terms and thus constitute a compartment with a crucial role in carbon sequestration in stable forms and with a long residence time.

\section{Conclusion}

The silvopastoral system was able to promote greater increases in the stocks of total organic carbon, organic carbon associated with minerals and the carbon in humic fractions, when compared to the conventional system. It also increased the values of particulate organic carbon and in-depth carbon management index.

Collection distances of soil samples in the silvopastoral system did not exert any significant influence on the changes in carbon stocks in the short term post-adoption of the system.

The native vegetation of Cerrado, for being a stable system, had the best indexes regarding the total organic carbon and the carbon in the fractions of the soil organic matter.

The silvopastoral system with two years of implantation is still not capable of having values equal or higher, in most of the evaluated attributes, when compared to the area of native vegetation of Cerrado.

Among the management systems, the carbon in the humic fractions of the soil proved to be more recalcitrant than aliphatic, meaning that the carbon stocks are in their most stable form.

\section{Literature Cited}

Baldotto, M. A.; Vieira, E. M.; Souza, D. O.; Baldotto, L. E. B. Estoque e frações de carbono orgânico e fertilidade de solo sob floresta, agricultura e pecuária. Revista Ceres, v. 62, n. 3, p. 301-309, 2015. https://doi.org/10.1590/0034-737X201562030010.

Balin, N. M.; Ziech, A. R. D.; Oliveira, J. P. M. de.; Girardello, V. C.; Stumpf, L.; Conceição, P. C. Frações da matéria orgânica, índice de manejo do carbono e atributos físicos de um Latossolo Vermelho sob diferentes sistemas de uso. Scientia Agraria, v. 18, n. 3, p. $85-$ 94, 2017. https://doi.org/10.5380/rsa.v18i3.53114.

Bernardino, F. S.; Garcia, R. Sistemas silvipastoris. Pesquisa Florestal Brasileira, n. 60, edição especial, p. 77-87, 2009. https://doi. org/10.4336/2009.pfb.60.77.
Blair, G. J.; Lefroy, D. B.; Lisle, L. Soil carbon fractions, base Don their degree of oxidation, and the development of a carbon management index for agricultural systems. Australian Journal of Agricultural Research, v. 46, n. 4, p. 1459-1466, 1995. https://doi. org/10.1071/AR9951459.

Brasil Neto, A. B.; Santos, C. R. C. dos.; Noronha, N. C.; Gama, M. A. P.; Carvalho, E. J. M.; Silva, A. R.; Guimarães, J. V. P.; Souza, P. I. A. de. Matéria orgânica e atributos físico-hídricos de um Latossolo sob diferentes sistemas de manejo. Agroecosssistemas, v. 10, n. 2, p. 147-164, 2018. https://doi.org/10.18542/ragros.v10i2.5134.

Braz, S. P. S.; Urquiaga, B. J. R.; Alves, C. P.; Jantalia, A. P.; Guimarães, C. A. dos; Santos, S. C.; Santos, E. F. M.; Pinheiro, R. M. Boddey. Soil carbon stock under productive and degraded Brachiaria pastures in the Brazilian Cerrado. Soil Science Society of America Journal, v. 77, n.3, p. 914-928, 2013. https://doi.org/10.2136/sssaj2012.0269. Cambardella, C. A.; Elliot, E. T. Particulate soil organic-matter changes across a grassl and cultivation sequence. Soil Science Society of America Journal, v. 56, n. 3, p. 777-783, 1992. https://doi. org/10.2136/sssaj1992.03615995005600030017x.

Campanha, M. M.; Nogueira, R. S.; Oliveira, T. S.; Teixeira, A. S.; Romero, R. E. Teores e estoques de carbono no solo de sistemas agroflorestais e tradicionais no semiárido brasileiro. Sobral: Embrapa Caprinos e Ovinos, 2009. 13p. (Embrapa Caprinos e Ovinos. Circular Técnica, 42). http://ainfo.cnptia.embrapa.br/ digital/bitstream/CNPC-2010/23049/1/ct42.pdf. 17 Fev. 2019.

Castro Neto, F.; Jacovine, L. A. G.; Torres, C. M. M. E.; Oliveira Neto, S. N. de.; Castrp, M. M. de.; Villanova, P. H.; Ferreira, G. L. Balanço de carbono - viabilidade econômica de dois sistemas agroflorestais em Viçosa. Floresta e Ambiente, v. 24, n.1 p. 1-9, 2017. https:// doi.org/10.1590/2179-8087.092114.

Cordeiro, L. A. M.; Vilela, L.; Marchão, R. L.; Kluthcoushi, J.; Martha Júnior, G. B. Integração lavoura-pecuária e integração lavourapecuária-floresta: Estratégias para intensificação sustentável do uso do solo. Cadernos de Ciência e Tecnologia, v. 32, n. 1/2, p. 15-53, 2015. https://seer.sct.embrapa.br/index.php/cct/article/ view/23294/13157. 10 Fev. 2019.

Ferreira, R. R. M.; Filho, J. T.; Ferreira, V. M. Efeitos de sistemas de manejo de pastagens nas propriedades físicas do solo. Semina: Ciências Agrárias, v. 31, n. 4, p. 913-932, 2010. https://doi. org/10.5433/1679-0359.2010v31n4p913.

Freitas, L. de.; Oliveira, I. A. de.; Casagrande, J. C.; Silva, L. S.; Campos, C. C. Estoque de carbono de Latossolos em sistemas de manejo natural e alterado. Ciência Florestal, v. 28, n. 1, p. 228-239, 2018. https://doi.org/10.5965/223811711812019136.

Köppen, W. Climatologia: con un estudio de los climas de la tierra. México: Fondo de Cultura Econômica, 1948. 479p.

Kunde, R. J.; Lima, A. C. R. de.; Silva, J. L. S. da.; Valgas, R. A.; Pilon, C. N. Qualidade do solo em sistemas de integração lavoura-pecuária no Bioma Pampa. Revista Brasileira de Ciências Agrárias, v. 13, n. 4, p. 1-8, 2018. https://doi.org/10.5039/agraria.v13i4a5591.

Lima, A. M. N.; Silva, I. R.; Neves, J. C. L.; Novais, R. F.; Barros, N. F.; Mendonça, E. S.; Demolinari, M. S. M.; Leite, F. P. Frações da matéria orgânica do solo após três décadas de cultivo de eucalipto no Vale do Rio Doce-MG. Revista Brasileira de Ciência do Solo, v. 32, n. 3, p. 1053-1063, 2008. https://doi.org/10.1590/ S0100-06832008000300014. 
Loss, A.; Ribeiro, E. C.; Pereira, M. G.; Costa, E. M. Atributos físicos e químicos do solo em sistemas de consórcio e sucessão de lavoura, pastagem e silvipastoril em Santa Teresa, ES. Bioscience Journal, v. 30, n. 5, p. 1347-1357, 2014. http://www. seer.ufu.br/index.php/biosciencejournal/article/view/22079. 30 Jan. 2019.

Lustosa Filho, J. F.; Nobrega, J. C. A.; Furtini Neto, A. E.; Silva, C. A.; Nóbrega, R. S. A.; Pragana, R. B.; Dias, B. O.; Gmach, M. R. Disponibilidade de nutrientes e teor de matéria orgânica sob diferentes sistemas de uso e manejo. Revista Brasileira de Ciências Agrárias, v. 12, n. 4, p.475-483, 2017. https://doi. org/10.5039/agraria.v12i4a5481.

Mascarenhas, A. R. P.; Sccoti, M. S. V.; Melo, R. R.; Corrêa, F. L. de O.; Souza, E. F. M. de.; Andrade, R. A.; Bergamin, A. C.; Mulle, M. W. Atributos físicos e estoques de carbono do solo sob diferentes usos da terra em Rondônia, Amazônia Sul-Ocidental. Pesquisa Florestal Brasileira, v. 37, n. 89, p. 19-27, 2017. https://doi. org/10.4336/2017.pfb.37.89.1295.

Matoso, S. C. G.; Salman, A. K. D. Fertilização orgânica em sistemas silvipastoris. Pesquisa Florestal Brasileira, v. 36, n. 88, p. 519-526, 2016. https://doi.org/10.4336/2016.pfb.36.88.982.

Muller, M. S.; Fancelli, A. L.; Dourado-Neto, D.; Garcia, A. G.; Ovejeto, R. F. L. Produtividade do Panicum maximum cv Mombaça irrigado, sob pastejo rotacionado. Scientia Agrícola, v. 59, n.1, p. 427-433, 2002. https://doi.org/10.1590/s010390162002000300003.

Nanzer, M. C.; Ensinas S. C.; Barbosa, G. F.; Barreta, P. G. V.; Oliveira, T. P. de.; Silva, J. R. M. da.; Paulino, L. A. Estoque de carbono orgânico total e fracionamento granulométrico da matéria orgânica em sistemas de uso do solo no cerrado. Revista de Ciências Agroveterinárias, v. 18, n. 1, p. 136-145, 2019. https:// doi.org/10.5965/223811711812019136.

Nicodemo, F.; Borges, W. L. B.; Souza, I. M. D. Atributos físicos do solo em quatro sistemas de uso da terra em São Carlos, SP. Revista Brasileira de Ciências Agrárias, v. 13, n. 2, p. 1-7, 2018. https:// doi.org/10.5039/agraria.v13i2a5524.

Oliveira, E. S.; Reatto, A.; Roig, H. L. Estoques de carbono do solo segundo os componentes da paisagem. Cadernos de Ciência e Tecnologia, v. 32, n.1-2, p.71-93, 2015. https://seer.sct.embrapa. br/index.php/cct/article/view/23296. 17 Fev. 2019.
Oliveira, M. de.; Ril, F. L.; Peretti, C.; Capellesso, E. S.; Sausen, T. L.; Budke, J. C. Biomassa e estoques de carbono em diferentes sistemas florestais no sul do Brasil. Perspectiva, v. 40, n. 149, p. 9-20, 2016. http://www. uricer.edu.br/site/pdfs/perspectiva/149_542.pdf. 02 Fev. 2019.

Resende, T. M.; Rosolen, V.; Bernoux, M.; Brito, J. L. S.; Borges, E. N.; Almeida, F. P. Atributos físicos e carbono orgânico em solo sob cerrado convertido para pastagem e sistema misto. Sociedade e Natureza, v. 27, n. 3, p. 501-514, 2015. https://doi. org/10.1590/1982-451320150310.

Santos, H. G.; Jacomine, P. K. T.; Anjos, L. H. C.; Oliveira, V. A.; Lubreras, J. F.; Coelho, M. R.; Almeida, J. A.; Cunha, T. J. F.; Oliveira, J. B. Sistema brasileiro de classificação de solos. 3.ed. Brasília: Embrapa, 2013. 353p.

Schettini, B. L. S.; Jacovine, L. A. G.; Torres, C. M. M. E.; Oliveira Neto, S. N. de.; Rocha, S. J. S. S.; Alves, E. B. B. M; Villanova, P. H. Estocagem de carbono em sistemas silvipastoris com diferentes arranjos e materiais genéticos. Advances in Forestry Science, v. 4, n. 4, p. 175-179, 2017. https://doi.org/10.34062/afs.v4i4.5042.

Silva, F. A. S.; Azevedo, C. A. V. The Assistat Software Version 7.7 and its use in the analysis of experimental data. African Journal of Agricultural Research, v.11, n. 39, p.3733-3740, 2016. https:// doi.org/10.5897/AJAR2016.11522.

Swift, R. S. Method for extraction of IHSS soil fulvic and humicacids. In: Sparks, D. L.; Page, A. L.; Helmke, P. A.; Loeppert, R. H.; Soltanpour, P. N.; Tabatabai, M. A.; Johnston, C. T.; Summer, M. E. (Eds.). Methods of soil analysis. Part 3. Chemical methods. Madison: Soil Science Society of America; American Society of Agronomy, 1996. p.1018-1020. (Soil Science Society of America Book Series, 5).

Torres, C. M. M. E.; Jacovine, L. A. G.; Oliveira Neto, S. N; Brianezi, D.; Alves, E. B. B. M. 2014. Sistemas Agroflorestais no Brasil: Uma abordagem sobre a estocagem de carbono. Pesquisa Florestal Brasileira, v. 34, n. 79, p. 235-244, 2014. https://doi. org/10.4336/2014.pfb.34.79.633.

Wink, C.; Reinert, D. J.; Tornquist, C. G.; Silva, I. R. Dinâmica do carbono e nitrogênio em plantações de eucalipto no Rio Grande do Sul. Revista Brasileira de Ciências do Solo, v. 39, p. 1623-1632, 2015. https://doi.org/10.1590/01000683rbcs20140182.

Yeomans, J. C.; Bremner, J. M. A rapid and precise method for routine determination of organic carbon in soil. Communications in Soil Science and Plant Analysis, v. 19, n. 13, p. 1467-1476, 1988. https://doi.org/10.1080/00103628809368027. 